\title{
Economia Criativa: assunto em pauta
}

\author{
DOI: http://dx.doi.org/10.20435/inter.v20i4.2806
}

Exportada do Reino Unido para todo o planeta, por diferentes matrizes ideológicas, a Economia Criativa merece cada vez mais um estudo aprofundado. Vista sob diferentes polifonias conceituais, empregada por diferentes vozes discursivas representadas por categorias e poderes políticos, a Economia Criativa entrou na pauta internacional da discussão econômica e política a partir dos anos 2000. Ao depender do conteúdo simbólico, segundo o IPEA (2013), ela pode ser vista como o conjunto de atividades em que se inclui a criatividade como fator de produção de bens e serviços ou ser vista também como matéria-prima e mercadoria. Ainda segundo o IPEA, a economia criativa relaciona-se à criatividade, à economia e à sociedade no uso da tecnologia e à propriedade intelectual.

A criatividade é o motor propulsor da inovação. A partir desta colocação, é viável deduzir que a economia criativa é um setor estruturado sobre a criatividade e, por isso mesmo, também sobre a novidade. Criatividade e inovação são palavras que caminham juntas quando as tratamos dentro de um contexto econômico. Nesse sentido, no âmbito da discussão da economia criativa, a criatividade deve ser entendida como um "monstro de três cabeças": criatividade artística (originalidade de ideias e formas de expressão), criatividade científica (curiosidade e disposição para experimentar e resolver problemas) e criatividade econômica (relacionada à inovação e à aquisição de vantagens e competitividades econômicas). Com relação às diferentes óticas conceituais, para Newbigin (2010), a origem da economia criativa se situa nas antigas tradições do trabalho cultural e industrial, isto é, no design, na produção, na decoração e na representação, quando estas começam a interagir com uma maior amplitude de atividades produtivas modernas, como a publicidade na mídia em movimento e a moda, por exemplo. Já a expressão surge em Howkins (2001) no sentido de uma atividade na qual a criatividade é tomada como capital intelectual, que, por sua vez, é tomado como matéria-prima para a produção de bens e serviços.

Para Marinho (2012), definem-se duas linhas de abrangência do conceito de economia criativa: a economia criativa como processo generalizado de criatividade e como cadeias de produção setorial, "privilegiando-se a criatividade como uma matéria-prima em abundância, e o pensamento econômico em segundo plano" (MARINHO, 2012, p. 10). Na segunda linha de abrangência, enfatiza-se o aspecto econômico e, nele, "Os setores, definidos em função de afinidades com o ambiente cultural e inovativo, misturam atividades tradicionais e contemporâneas, integradas por criatividade, tecnologia e conhecimento" (MARINHO, 2012, p. 10). A partir Relatório do Desenvolvimento Humano 2015 das Nações Unidas (PROGRAMA DAS NAÇÕES UNIDAS PARA O DESENVOLVIMENTO [PNUD], 2015), são as características valorizadas no mundo do trabalho, como conhecimento, competências e atributos de personalidade, a base conceitual da economia criativa, no sentido de que a revolução tecnológica favorece os indivíduos com um capital humano mais elevado.

Ao produzir conhecimentos, a ciência assume um compromisso em sua disseminação, ou seja, torná-los públicos, demonstrando à comunidade científica as atividades realizadas; neste contexto, as produções científicas publicadas em periódicos ou livros tornam-se o veículo mais eficaz da disseminação do conhecimento e visibilidade científica.

O levantamento do conhecimento da produção existente é importante para todo e qualquer trabalho acadêmico, pois sua finalidade é poder estabelecer os avanços existentes e os limites ou as dispersões a respeito de determinada temática. Esta revisão documental se fundamenta em abordagem de natureza qualitativa/interpretativa e, a partir desta, há possibilidades de se identificar não só as problemáticas significativas como também a ampliação dos saberes sobre determinado campo de conhecimento.

Neste sentido, o número 4 da Interações traz, entre seus artigos, o texto intitulado "A institucionalização da Economia Criativa no estado de Mato Grosso do Sul", de autoria de Vanessa Pancheri Teixeira, William Teixeira e Elcio Gustavo Benini, constituído pela análise de documentos oficiais disponíveis no Diário Oficial do Estado de Mato Grosso do Sul. Por meio da pesquisa qualitativa e da análise documental, 
faz-se o levantamento da Economia Criativa na administração pública estadual.

Se falamos de criatividade, é importante ressaltar neste volume o artigo "QR Code como incremento ao turismo cultural do barroco centro histórico de São Francisco do Sul, SC". Nele, os autores apresentam os resultados da elaboração de um roteiro turístico cultural no centro histórico de São Francisco do Sul, SC. Já o artigo "Parques verdes urbanos e transformação de comportamento: uma proposta de framework teórico entre a Transformative Service Research e a Service Dominant Logic" propõe um modelo de pesquisa hipotético entre parques verdes urbanos e a transformação de comportamento de seus usuários, no uso de uma revisão bibliométrica da Transformative Service Research na base cientifica: web of Science. No artigo "Princípios de economia circular para o desenvolvimento de produtos em arranjos produtivos locais", os autores fazem uma revisão sistemática da literatura e análises documentais, possibilitando a composição de um modelo de desenvolvimento de produtos orientado ao pensamento do ciclo de vida e à economia circular.

O presente número de Interações conta com 21 artigos que envolvem na perspectiva interdisciplinar um olhar diverso voltado às temáticas que contemplam as linhas editoriais da revista, ou seja, do desenvolvimento regional, aos usos etnobotânicos, às cadeias produtivas, aos arranjos produtivos locais, à biodiversidade, às fontes e redes de informação, perpassando pelas comunidades tradicionais e pelos modelos interdisciplinares para análise teórica.

O Comitê de Redação neste n. 4/2019 mais uma vez agradece a todos os autores, à equipe editorial, aos Membros do Conselho Editorial e a todos os avaliadores ad hoc, pelo trabalho ao longo de 2019. Vale ainda sublinhar que Interações, órgão de divulgação científica do Programa de Mestrado e Doutorado em Desenvolvimento Local da Universidade Católica Dom Bosco - programa recomendado pela CAPES e credenciado pelo MEC com a nota 5 -, solicita que todos os pesquisadores interessados pelo tema do Desenvolvimento enviem trabalhos inéditos para publicação neste veículo distribuído nacional e internacionalmente, entre instituições universitárias e organismos de pesquisa.

\section{Arlinda Cantero Dorsa ${ }^{1}$ \\ Editora chefe da Interações}

\section{REFERÊNCIAS}

HOWKINS, John. The creative economy: how people make money from ideas. London: Penguin UK, 2001.

INSTITUTO DE PESQUISA ECONÔMICA APLICADA (IPEA). Panorama da Economia Criativa no Brasil. Brasília: Rio de Janeiro: IPEA, 2013.

MARINHO, Heliana. Economia Criativa. In: SERVIÇO BRASILEIRO DE APOIO ÀS MICRO E PEQUENAS EMPRESAS (SEBRAE). Economia criativa do Rio de Janeiro e as MPE. Rio de Janeiro: SEBRAE, nov. 2012. p. 7-15. [Boletim Quadrimestral].

NEWBIGIN, John. A economia criativa: um guia introdutório. Tradução de Diana Marcela Rey e João Loureiro. London: British Council, 2010. (Série Economia Criativa e Cultura, v. 1).

PROGRAMA DAS NAÇÕES UNIDAS PARA O DESENVOLVIMENTO (PNUD). Relatório do Desenvolvimento Humano 2015: o trabalho como motor do desenvolvimento humano. PNUD, 2015. Disponível em: http://hdr.undp.org/ sites/default/files/hdr15_overview_pt.pdf. Acesso em: 15 out. 2019.

\section{Sobre a autora:}

Arlinda Cantero Dorsa: Doutora em Língua Portuguesa pela Pontifícia Universidade Católica de São Paulo (PUC-SP). Professora na Universidade Católica Dom Bosco (UCDB). E-mail: acdorsa@ucdb.br, Orcid: http://orcid.org/0000-0002-1120-0273

\footnotetext{
${ }^{1}$ Universidade Católica Dom Bosco (UCDB), Campo Grande, Mato Grosso do Sul, Brasil.
} 